Article

\title{
Social Representations of the Body and Sexual Satisfaction in Mastecomized Women and their Partners
}

\author{
Tamiris Molina Ramalho Hirschle ${ }^{1, *}$ \\ Orcid.org/0000-0002-7456-1025 \\ Silvana Carneiro Maciel $^{1}$ \\ Orcid.org/0000-0003-1489-1126 \\ Geane Karla de Amorim ${ }^{1}$ \\ Orcid.org/0000-0001-7190-0813
}

${ }^{1}$ Universidade Federal da Paraíba, João Pessoa, PB, Brazil

\begin{abstract}
Women who undergo mastectomy and their partners face a transformed body, which has several implications, including an effect on their sexual satisfaction. The aims of the present study were to understand the social representations of the female body, the social representations of the mastectomized body, and the level of sexual satisfaction of these couples. Ten couples (mastectomized women and their partners) were included in the study. The study instruments were a scale of sexual satisfaction and the free word association technique (FWAT), using the expressions "female body" and "mastectomized female body" as stimuli. The mastectomized body was observed to have more negative representations related to the appearance of the breast(s). Couples' sexual satisfaction decreased after mastectomy, interfering with the women's self-image and with marital life. The need to expand public policies targeting this population is emphasized, with a focus on reconstructive surgery and work with social representations to revise the sexualization of breasts. Such policies can improve quality of life for mastectomized women and their partners.
\end{abstract}

Keywords: Social representations, mastectomized women, sexual satisfaction.

\section{Representações Sociais sobre o Corpo e Satisfação Sexual de Mulheres Mastectomizadas e seus Parceiros}

\section{Resumo}

Mulheres que passam pelo procedimento da mastectomia e seus parceiros se deparam com o corpo transformado que remete a diversas implicações incluindo a satisfação sexual. Este trabalho objetiva compreender as representações sociais acerca do corpo da mulher e do corpo mastectomizado e o nível de satisfação sexual dos casais. Participaram do estudo 10 díades (mulheres mastectomizadas e seus parceiros) e utilizou-se como instrumento uma escala de satisfação sexual e a Técnica de Associação Livre de Palavras com os estímulos corpo da mulher e corpo da mulher mastectomizada. Observou-se que o corpo mastectomizado possuiu mais representações negativas vinculadas à aparência da mama,

* Mailing address: Avenida Manoel Deodato, $n^{\circ}$ 821, Apto 203-A, Bairro Torre, João Pessoa, PB, Brazil 58040181. E-mail: tami.ramalho@gmail.com

Support: Coordenação de Aperfeiçoamento de Pessoal de Nível Superior (CAPES). 
impactando no nível de satisfação sexual do casal, onde se constatou que este diminui após a mastectomia, interferindo na autoimagem e na vida conjugal. Destaca-se a necessidade de ampliação de políticas públicas voltadas para essa população visando a cirurgias reparadoras e ao trabalho com as representações sociais visando redimensionamento da sexualização das mamas impactando na melhoria da qualidade de vida dessas mulheres e de seus parceiros.

Palavras-chave: Representações sociais, mulheres mastectomizadas, satisfação sexual.

\section{Representaciones Sociales sobre el Cuerpo y Satisfacción Sexual de Mujeres Mastectomizadas y sus Parejas}

\section{Resumen}

Tanto las mujeres que han sido sometidas a mastectomía como sus parejas se encuentran ante un cuerpo trasformado el cual remite a diversas implicaciones, entre otras; la satisfacción sexual. El objetivo de este trabajo estriba en comprender las representaciones sociales del cuerpo de la mujer y del cuerpo mastectomizado y ahondar en el nivel de satisfacción sexual de estas parejas. En el estudio han participado 10 matrimonios (mujeres mastectomizadas y sus parejas) y los instrumentos utilizados han sido una escala de satisfacción sexual y la Técnica de Asociación Libre de Palabras con los estímulos cuerpo de la mujer y cuerpo de la mujer mastectomizada. Hemos observado que el cuerpo mastectomizado obtuvo más representaciones negativas vinculadas a la apariencia de la mama, interviniendo en el nivel de satisfacción sexual del matrimonio, donde se constató que este disminuye después de la mastectomía, perjudicando la autoimagen y la vida en pareja. Se destaca la necesidad de la ampliación de políticas públicas volcadas para esta población hacia las cirugías restauradoras y al trabajo con las representaciones sociales con vistas al redimensionamiento de la sexualización de las mamas con el objetivo de mejorar la calidad de vida de estas mujeres y de sus parejas.

Palabras clave: Representaciones sociales, mujeres mastectomizadas, satisfacción sexual.

Breast cancer is the main form of cancer affecting women worldwide. Approximately 1.67 million new cases were expected in 2012 globally, corresponding to $25 \%$ of all cancers diagnosed among women, with approximately 520,000 deaths estimated for that same year. It is the second largest cause of death from cancer in developed countries, second only to lung cancer, and the main cause of death from cancer in the developing world (Instituto Nacional de Câncer [INCA], 2014).

Primary treatment typically consists of surgery, which may be restricted to the tumor, involve the surrounding tissues or remove the breast entirely (radical mastectomy) together with the axillary lymph nodes and the pectoral muscles. In addition, the patients may be subjected to other treatments, such as chemotherapy, radiotherapy and hormone therapy (Cesnik \& Santos, 2012; Santos \& Vieira, 2011).
The term cancer carries a strong stigma because as a rule people immediately associate it with death. In the case of women, breast cancer causes even more fear because it affects a highly valued part of the body that plays a significant role in female sexuality and identity in many cultures (Silva et al., 2012).

In present-day society, the breasts are seen as a bodily symbol of sexuality and womanhood and are related to the construction of the female identity. Hence, any pathology affecting them leads to a loss of self-esteem and changes in the self-image of women, resulting in feelings of inferiority and rejection (Seara, Vieira, \& Pechorro, 2012). This process may be even more difficult in the case of women subjected to mastectomy, a procedure that causes an obvious change in body shape, because such change elicits feelings of strangeness, suffering and self-depreciation resulting from a refusal to accept the loss of a 
breast. Therefore, a thorough understanding of patients' reactions must take into account the symbolic component associated with the breasts, which is related to motherhood, fertility, reproduction and sexuality (Angerami, 2013; Santos, Dias, Lacerda, Barreto, \& Santos, 2008). At the level of representation, the breasts are typically associated with pleasurable acts, which does not align with being the target of a painful and mutilating medical intervention. From the perspective of the affected woman, the possibility of developing a breast disease can compromise the construction of a female self-image and the actualization of her sexuality (Scorsolini-Comin, dos Santos, \& Souza, 2009).

Some women with breast cancer tend to perceive and represent their bodies as mutilated and see themselves as monsters, as abnormal and deficient individuals. They may no longer feel they are beautiful or may feel they have lost their womanhood. In addition, breast cancer can affix social stigma to patients, with negative effects on their body image, social interactions, and sometimes also on their relationship with their marital partners, as many patients report experiencing sexual rejection from their partners, which can affect their sexual satisfaction (Silva et al., 2012).

Sexuality is an integral part of the human experience, encompassing the most intimate feelings of individuality. It is present in all types of interactions and contexts and is directly related to our well-being and self-experience as sexual beings. Therefore, it is evident that sexuality cannot be considered as something alien to health, as it is essential for the well-being and formation of human self-concept (Santos, 2012; Sheppard \& Ely, 2008).

The reaction to the full process of experiencing breast cancer impacts not only the affected women but also their family environment and social setting, imposing moreover physical and emotional limitations. Such impact is potentiated by invasive treatments, which involve reduction or interruption of leisure activities, domestic activities, employment activities, and sexuality. Such changes require a continuous need to adapt to treatment and to a new lifestyle, as empha- sized by Romeiro, Both, Machado, Lawrenz, and Castro (2012).

As a result of the aforementioned considerations and the fact that such adjustments concern the wider sphere of social interactions anchored in a social layer permeated by representations shared by society, social representation theory is used to support this study. Social representations, in general, can be seen as a "worldview" that individuals or groups possess and employ in the form of acting and positioning themselves. However, such worldview should not be reduced to the status of a mere reflection of reality; rather, it is a meaningful organization. It is this reappropriated reality that constitutes reality itself for the individual or group (Chaves \& Silva, 2011). Thus, the representations of the mastectomized body for couples can be studied via two processes: objectification, which refers to the way in which the constituent elements of a representation are organized and the way in which these elements acquire materiality; and anchoring, which refers to the fact that any treatment of information demands points of reference - one thinks of the object of a representation based on previously established experiences and schemes. These two processes are intimately linked to one another and are shaped according to social factors (Moscovici, 2012).

In the light of social representation theory, the view of the body, understood as a representational object, has several implications for how people see themselves and relate to the world around them. In the case of the sample analyzed here, the body that is the object of study is in a state of change. One implication within this context is how mastectomized women perceive themselves and how their partners perceive them. Considering the social representations of the mastectomized women and their partners is relevant to understanding how couples represent the removal of the breast, an organ with high social value as a component of womanhood and sexuality, and how such representation impacts couples' relationships and their sexual satisfaction in particular. Therefore, the aim of the present study was to investigate the shared social representations of the female body and of 
the mastectomized body among mastectomized women and their partners and the level of sexual satisfaction of the couples. This aim was accomplished by accessing their experiences and narratives and the new meanings attributed to the transformed body. The study was designed based on social representation theory from its dimensional perspective, which is characterized by the study of the content of representations encompassing the totality of expressions, ideas, images and values regarding a subject.

\section{Methods}

\section{Participants}

The present descriptive quantitative-qualitative study was conducted with 10 couples (10 mastectomized women and their partners) recruited by means of non-probabilistic convenience sampling. Women who underwent mastectomy (with or without breast reconstruction) at least one year prior and had the same partner before and after the procedure were included. The average age of the sample was 50 years old; the average duration of marital cohabitation was 24 years; $55 \%$ of the sample had some degree of higher education; $90 \%$ of the men and $60 \%$ of the women had a remunerated job. Approximately $60 \%$ of the women had had their mastectomy in the previous 1 to 5 years; $50 \%$ of them had had breast reconstruction, of which all were satisfied with the results; among the women who did not undergo breast reconstruction only one reported not being satisfied.

\section{Instruments}

The free word association technique (FWAT) was used to investigate and analyze the representational content attributed to the female body and the mastectomized female body by the mastectomized women and their partners. The expressions "female body" and "mastectomized female body" were used as inducing stimuli to establish a point of comparison between the unchanged body and the mastectomized body. In addition, a scale of sexual satisfaction was applied, in which the respondents graded their level of sexual satisfaction before and after mastectomy from 0 to 10 .

\section{Procedures for Data Collection}

Data collection was performed at a nongovernmental organization (NGO), a hospital and the interviewees' home. The sample was recruited by means of the snowball technique, which is typically used for rare, unknown or difficult-to-contact populations (Dewes, 2013). After the participants signed an informed consent form, the FWAT was applied: the respondents were asked to provide five words in one minute for each inducing stimulus spoken by the interviewer. Next, the participants responded to the Sexual Satisfaction Scale.

\section{Procedures for Data Analysis}

The thematic content analysis technique formulated by Bardin (1977) was used for the data collected by means of FWAT. This analysis sought to establish a posteriori representation categories for the words provided by the study participants. Content analysis was selected because, first, it can be applied to any communication involving transferal of meanings from a sender to a receiver. Second, this technique involves systematic procedures to describe the content of messages and to extract from them indicators allowing the inference of knowledge regarding the conditions of production of the messages (Ramalho et al., 2014).

Content analysis can be defined as:

A set of techniques for analysis of communication aiming at obtaining, by means of systematic and objective procedures to describe the message content, (quantitative or non-quantitative) indicators allowing for the inference of knowledge relative to the conditions of production/reception (inferred variables) of messages. (Bardin, 1977, p. 42)

According to this definition, content analysis employs a set of partial and complementary techniques to systematize and explain content and its meanings through logical, well-justified deductions using the sender and the context or 
effects of the message as reference (Maciel \& Melo, 2011).

According to Minayo (1998) there are different types of content analysis, including thematic content analysis, which is used in the present study. This type of analysis seeks to encode or characterize a segment by placing it into one of the equivalence classes determined from the meanings. The analysis works in stages, corresponding to two different time-points: the first consists in the inventory or isolation of elements by fragmenting the text into units and categories; the second involves analytical reclustering, whereby the messages are classified or organized based on their isolated elements.

According to Bardin (1977) and Vala (2003) three basic operations must be performed in content analysis. The first is "unfocused reading"; the investigator approaches the text gradually, coming and going between the notes he/she made and the analyzed material.

The second operation concerns the definition of categories. Upon analyzing a document, its content has to be categorized and classified to reduce its complexity. This operation facilitates the subsequent formulation of explanations and grasping of reality. As a rule, the categories are created at the time of analysis, based on the material. The categories indicate the core meaning of the concept one intends to grasp as well as other indicators that describe the semantic field of the concept.

The third operation is the determination of the units of analysis, of which there are three types: recording or thematic unit, context unit and enumeration unit. According to Vala (2003, p. 114), "recording units are certain content segments that are characterized by placing themselves in a given category". Bardin (1977) observes that context units contribute to the understanding of meanings because in addition to encoding and clustering the recording units, they attribute an involved meaning to them. Finally, enumeration units are used to quantify the presence or absence of units in discourse.

These operations allow the classification of elements according to their similarities and dif- ferences, followed by reclustering according to their common characteristics. In addition, statistical operations can be performed, from simple frequency calculations to others involving complex statistical procedures (Maciel \& Melo, 2011).

Because content analysis as a data treatment technique is open to the investigator's interpretation, it can exhibit bias. For this reason, additional investigators with broad experience in the technique are required to validate the categories and subcategories established by one investigator. This procedure is known as analysis by judges, and in the present study it was performed by two investigators with broad experience in content analysis. Five interviews were delivered to each judge, who performed all the steps of content analysis. Subsequently, the suggested categories and subcategories were compared, and those formulated by at least two examiners (both judges or one judge and the investigator) were retained.

The results from the Sexual Satisfaction Scale were analyzed using Statistical Package for the Social Sciences (SPSS) for Windows 8 - version PASW 21.0. This scale was applied to describe the level of sexual satisfaction from the couples' perspective. For this purpose, descriptive analysis, including mean, standard deviation and simple frequencies, was performed.

\section{Ethical Issues}

The present study complied with the ethical requirements described in the Brazilian National Health Council (Conselho Nacional de Saúde [CNS]) Resolution number 466/12, which addresses ethics in research involving human beings and was approved with protocol number 0276/14.

\section{Results and Discussion}

The results of the thematic content analysis of the words that emerged in the FWAT applied to the couples are described next. The data are presented as tables of simple frequencies followed by the corresponding discussion. 
Table 1

Categories of Representations Corresponding to the "Female Body" and "Mastectomized Female Body" Stimuli

\begin{tabular}{|c|c|c|}
\hline \multicolumn{3}{|c|}{ Female Body } \\
\hline Categories & Men & Women \\
\hline $\begin{array}{l}\text { Body } \\
\text { appearance }\end{array}$ & $\begin{array}{c}F=32 \\
\text { e.g.: beautiful, legs, eyes, perfection }\end{array}$ & $\begin{array}{l}\qquad F=42 \\
\text { e.g.: beautiful, perfect, fat, thin }\end{array}$ \\
\hline Affectivity & $\begin{array}{c}F=7 \\
\text { e.g.: love, good, endearment, motherhood }\end{array}$ & $\begin{array}{c}F=6 \\
\text { e.g.: self-esteem, identity, courage, care }\end{array}$ \\
\hline $\begin{array}{l}\text { Sexual } \\
\text { elements }\end{array}$ & $\begin{array}{c}F=11 \\
\text { e.g.: sex, desire, hot, satisfying }\end{array}$ & $\begin{array}{c}F=1 \\
\text { E.g.: sensuality }\end{array}$ \\
\hline \multicolumn{3}{|c|}{ Mastectomized Female Body } \\
\hline Categories & Men & Women \\
\hline $\begin{array}{l}\text { Body } \\
\text { appearance }\end{array}$ & $\begin{array}{c}\qquad F=21 \\
\text { e.g.: lack, different, the same }\end{array}$ & $\begin{array}{l}F=22 \\
\text { e.g.: lack, mutilation, shame, reconstruction }\end{array}$ \\
\hline Affectivity & $\begin{array}{c}F=24 \\
\text { e.g.: pity, sadness, difficult, prejudice }\end{array}$ & $\begin{array}{c}F=26 \\
\text { e.g.: acceptance, difficult, change, fear }\end{array}$ \\
\hline $\begin{array}{c}\text { Sexual } \\
\text { elements }\end{array}$ & $\begin{array}{c}F=2 \\
\text { e.g.: sex, desire }\end{array}$ & $F=0$ \\
\hline
\end{tabular}

Note. F is the frequency of words mentioned.

Table 1 describes the results corresponding to the female body and mastectomized female body stimuli. The first stimulus was applied to obtain the representations of the mastectomized women and their partners with regard to the female body generally as well as to compare them with the representations elicited by the second stimulus, the mastectomized female body. In both cases analysis provided three (3) categories, which were named: body appearance, affectivity and sexual elements, indicating the importance of the stimulus to the couple.

The female body stimulus produced 99 expressions. The category with the largest number of expressions evoked was body appearance, corresponding to $75 \%$ of the total, while affectivity corresponded to $13 \%$ of the total and sexual elements to $12 \%$. The mastectomized female body stimulus produced 95 expressions, similarly categorized as body appearance, with 43 expressions corresponding to $45 \%$ of the total, affectivity comprising 50 expressions with $52 \%$ of the total, and sexual elements, which were mentioned only by the men with $3 \%$ of the total.

Among the main differences in the representations of the investigated objects, the representations of the female body were related more to body appearance, with considerable weight on sexual elements. In contrast, with regard to the mastectomized body, the representations focused first on affectivity, followed by body appearance. In addition, differences were also found concerning other aspects, which are described in detail below.

The representations in the body appearance category relative to the female body stimulus were objectified as "beautiful", "perfect", "legs", fat" and "thin", which represent the physical side of the female body, corresponding to positive characteristics, such as beauty and perfection, or body components, such as legs, eyes, face and mouth. In turn, the representations in this category for the mastectomized female body stimulus were objectified by words such 
as "mutilation", "lack", "shame", "reconstruction" and "different". These expressions denote a more negative view, which indicates that the mastectomized body is associated with negative images related to the loss of the breast(s).

The expressions somewhat differed in terms of their meanings between the couples' members; the men's representations included "different" and "lack" but also "the same". The women's partners tend to pass through the process more quickly and accept the changes more easily, as Salles, Cecílio, Pereira, and Maia, (2012) assert. Since the men directly and intimately cohabitate with the mastectomized women, their feelings and experiences may serve as basis for the development of strategies of support for the women and their families throughout the process. The studies conducted with couples by Ferreira, Farrago, Diniz dos Reis and Funghetto (2011) corroborate the results of the present study. According to these authors, the men consensually asserted that breast removal was not associated with any change, as the most important aspect was for the women to remain alive.

The women expressed more negative representations because they are directly affected by the change in their bodies, which alters their body image, and the loss of the breast(s) translates into feelings of embarrassment, inferiority, shame, inhibition and low self-esteem. The women begin to feel unable to behave as women relative to society, their family and partners. Upon providing representations of the mastectomized body, the women do not speak from an external perspective but are entangled with the represented object, which is full of the subjectivity that permeates the repercussions of the fact of being the subject/object of such a marked body.

These representations of the female body, characterized as perfection and beauty, reflect the social construction of the concept of the female body, which requires it to be in good shape. Such elements are socially shared and influence the self-esteem of women who undergo changes in their bodies (Salles et al., 2012; Siqueira \& Faria, 2007).

Relative to the category affectivity for the female body stimulus, both types of social ac- tors objectified their representations as "love", "endearment", "good" and "self-esteem". Nevertheless, they also differed in some expressions. For the men this is an issue of endearment, motherhood and love, denoting the idea that the men see their female partners as caregivers, maternal and kind, these being representations related to women and socially shared. In turn, the women raised issues related to self-esteem, identity and care, which denote a concern with their bodies as determinants of their self-esteem and identity.

As concerns the representations associated with the mastectomized female body stimulus, the category affectivity was prominent among both the men and the women and objectified by words such as "pity", "difficult", "sadness", "prejudice", "acceptance" and "change". These expressions denote that the stimulus was linked to representations of an affective nature, associated with feelings such as sadness but also with acceptance. In this category, the mastectomized female body was objectified in a more negative manner than the representations relative to the female body (Table 1). Affectivity was linked to issues related with penalization. The body came to be represented as a rejected body and the target of prejudice. These feelings contribute to the impaired self-image and even the social exclusion of the women (Ibiapina et al., 2015).

Differences between the men and the women were evident with regard to the sexual elements category relative to both the female body and mastectomized female body stimuli, in which the men stood out. This category included representations objectified as "desire", "sex", "hot" and "satisfying", anchored in the images related to the female body as object of desire or as sexual symbol. Such representations appear in the general media, in a cosmeticized, fetish-like manner, impregnated with erotic, seductive, sensory and sensual connotations, as shown, for instance, by advertising targeting men, where the female image is reinforced as a sexual symbol related to products assumed to be desirable to or a source of status for men (Souza, Oliveira, Nascimento, \& Carvalho, 2013).

As a result, publicized in a stereotyped manner in the formal and informal mass media, the 
female image in the media constructs a pattern that confirms the cult of the body, leading to health-related problems, as women are affected by the impossibility of attaining the desired, perfect body idolized in media imagery (Sá-Serafim, 2013).

This raises the issue of the sexuality of women with breast cancer who have undergone mastectomy because they do not express representations of sexuality linked to the body, which may directly interfere with their sexuality and marital relationship. One of the functions of social representations is orientation (i.e., a guide

for social behaviors and practices). They constitute a system of pre-encoding of reality, a guide for action. In addition, social representations allow for a posteriori justification of behaviors and definition of attitudes (Chaves \& Silva, 2011). As a result, the representations of the mastectomized body produced by both women and their partners may lead to changes in their behaviors, including with regard to exercising sexuality.

As an attempt to analyze the couples' perception of the impact of mastectomy on their sexuality, the results of the Sexual Satisfaction Scale, as simple frequencies, are described in Table 2.

Table 2

Level of Sexual Satisfaction of Couples Before and After Mastectomy

\begin{tabular}{ccccccccccccc}
\hline Items & 7 & 8 & 9 & 10 & $M$ & 4 & 5 & 7 & 8 & 9 & 10 & $M$ \\
\hline Men & 1 & - & 3 & 6 & 9.4 & 1 & 2 & 1 & - & 3 & 3 & 7.8 \\
Women & - & 2 & 2 & 6 & 9.4 & - & 3 & 2 & 3 & - & 2 & 7.3 \\
\hline
\end{tabular}

Note. $\mathrm{M}$ is the mean sexual satisfaction described by the participants on a $0-10$ scale before and after mastectomy.

As the results show, the couples reported a reduction in their sexual satisfaction after mastectomy. Scores 7, 8, 9 and 10 exhibited the highest percentages before surgery, which indicates that the participants rated their sexual satisfaction before mastectomy between good and excellent. The range of scores attributed after surgery is wider, including scores 4,5 , 7, 8, 9 and 10, which indicates that the sexual satisfaction of some couples decreased after mastectomy. For both genders, the mean score of sexual satisfaction before surgery was 9.4, with a standard deviation of 0.51 . The mean score after surgery was 7.5 , with a standard deviation of 2.08. In addition, the mean score of sexual satisfaction after surgery was somewhat lower among the women than among the men, as Table 2 shows.

Some studies corroborate the results of the present one. For instance, Santos et al. (2008) assessed satisfaction with sexual intercourse before and after occurrence of breast cancer. The results indicated that after the onset of disease, the women tended to ask their partners for sex less often, and consequently, the frequency of intercourse decreased. The women added that before the occurrence of breast cancer their sexual relationship with their partners was very good, intercourse being both satisfactory and frequent. There are no reports in the literature of a pattern in the reaction of partners upon restarting sexual life after cancer and mastectomy. Some men tend to distance themselves, while others become even more affectionate and kind toward their partners. Some women fear their partners will not accept their new condition, which may be due to the association the women establish between sexuality and certain body parts including the breasts, which leads them to believe that the absence of the breast(s) will necessarily make their partners distance themselves due to their altered body image (Santos et al., 2008).

In a study involving mastectomized women in which women with breast cancer, women with sexual dysfunction and women from the overall population were compared, Speer et al. (2005) found that the scores of the participants with breast cancer were significantly lower in 
all the dimensions of sexual functioning (desire, arousal, lubrication, orgasm, satisfaction and pain) than those of the healthy control group but higher than those of the women with sexual dysfunction in all the dimensions, except for desire and pain. In addition to the aforementioned physical factors, the women's disturbed body image interferes with how the couple relates from the sexual standpoint. In their studies, Sheppard and Elly (2008) found obliteration of the sexual relationship due to the difficulty of coping with the situation posed by breast cancer. Some couples eventually separated because the men were not able to cope with the situation. In turn, the participants' sexual satisfaction was impaired because the women wrongly believed that their partners had lost interest and would reject them due to their body appearance, which made them distance themselves both emotionally and sexually.

Breast cancer triggers several changes in the lives of women, which interfere with their feelings about themselves and their perspective on life. Contradictory feelings develop, including hope for a cure and fear of relapse, the need to cope with the mutilation resulting from mastectomy, concerns with womanhood and with the reactions of partners to mastectomy, resulting in low self-esteem (Salles et al., 2012). Associated with these factors, the partner's reaction is directly related to recuperation and to the recovery of the body and sexual identity. Indeed, the relevance of the support afforded to women with breast cancer is shown in a study that found that women with a partner exhibited improvement in their emotions and in the interpersonal relationship (Ferreira et al., 2011).

Based on the study's findings, understanding what occurs with regard to mastectomized women and their partners based on the representations both develop with regard to the female body, the mastectomized female body and their sexual satisfaction was extremely relevant to comprehending the experiences and the possible repercussions of such representations on the lives of the women and their partners as concerns the representations of the body and their implications for sexuality.

\section{Final Considerations}

Overall, the results of the present study show differences in the representations of the female body and the mastectomized female body. The female body was objectified by the couples as perfect, beautiful and sexual. These representations are anchored in the social imagery of the female body, which constructs it as sexual, feminine, perfect and free from flaws. In contrast, the mastectomized female body was objectified in terms of lacking, as ugly, mutilated and sad. These representations are anchored in the notion that the female body must be healthy and perfect, while the mastectomized body carries a stigmatized disease, cancer. The results further indicated reduction in the couples' sexual satisfaction. Nevertheless, they rated their sexual satisfaction as good, inasmuch as the couples attempted to develop strategies to live with the lack of one or both breasts and the repercussions of this condition. In addition, the social support provided by the partners is a factor that contributes to coping and acceptance.

Few studies have addressed the couple's experience facing female breast cancer; hence, future studies are needed to improve the understanding of this situation, in particular when one considers the fact that in most studies the main concern is to investigate the repercussions on the lives of the women only, while dismissing the views and reactions of their partners, although they also witness and experience all the stages of the disease. In addition, the women relate mastectomy to prejudice, shame and fear to expose themselves with their scars and lack of breast(s) to other people. Thus, one might recommend that future studies investigate more thoroughly aspects related to prejudice against mastectomized woman.

The authors believe that the present study might serve to stimulate reflection on subjects related to mastectomized women and their partners, more particularly the representations of the mastectomized body and couples' sexual satisfaction, thus enabling the development of strategies for the care of and coping with disease as well as for the recovery of the integrity, self- 
esteem and self-image of the affected women. There is also a need for healthcare professionals and others who provide care to this population to develop programs of intervention and groups of discussion to provide more information and care strategies to help in the overcoming of the psychological, emotional and social implications of breast cancer and mastectomy.

\section{References}

Angerami, V. A. (2013) A subjetivação do câncer. In V. A. Angerami-Camon \& K. C. Gaspar (Eds.), Psicologia e câncer. São Paulo, SP: Casa do Psicólogo.

Bardin, L. (1977). Análise de conteúdo. São Paulo, SP: Martins Fontes.

Cesnik, V. M., \& Santos, M. A (2012). Desconfortos físicos decorrentes dos tratamentos do câncer de mama influenciam a sexualidade da mulher mastectomizada. Revista da Escola de Enfermagem USP, 46(4), 1001-8. Retrieved from www. ee.usp.br/reeusp/

Chaves, A. M., \& Silva P. (2011). Representações Sociais. In L. Camino, A. R. R. Torres, M. E. O. Lima \& M. E. Pereira. (Eds.), Psicologia Social: Temas e teorias (p. 636). Brasília, DF: Technopolitik.

Dewes, J. O. (2013). Amostragem em Bola de neve e respondent-driven simpling: Uma descrição de métodos (Monograph). Departamento de Estatística. Universidade do Rio Grande do Sul, Porto Alegre, RS, Brazil.

Ferreira, D. B., Farrago, P. M., Diniz dos Reis, P. E., \& Funghetto, S. S. (2011). Nossa vida após o câncer de mama: Percepções e repercussões sob o olhar do casal. Revista Brasileira de Enfermagem, 64(3), 536-44. Retrieved from http://www. scielo.br/pdf/reben/v64n3/v64n3a18.pdf

Ibiapina, A R. S., Maia, J. M., Silva, L. D. C., Fernandes, M. A., Filho, A. A. I. C. \& Fernandes, R. O. (2015). Aspectos psicoemocionais de mulheres pós-mastectomizadas participantes de um grupo de apoio de um hospital geral. Revista Interdisciplinar, 8(3), 135-142.

Instituto Nacional de Câncer. (2014). Incidência do Câncer no Brasil. Rio de Janeiro, RJ: Author. Retrieved from http:/www2.inca.gov.br/wps/ wcm/connect/acoes_programas/site/home/no- brasil/programa_controle_cancer mama/conceito_magnitude

Maciel, S. C., \& Melo, J. R. F. (2011). O recurso da entrevista e da análise de conteúdo em pesquisas qualitativas. In M. P. L. Coutinho \& E. R. A. Saraiva (Eds.), Métodos de pesquisa em Psicologia Social, perspectivas qualitativas e quantitativas (pp. 175-204). João Pessoa, PB: Editora Universitária.

Minayo, M. C. S. (1998). O desafio do conhecimento: Pesquisa qualitativa em saúde ( $5^{\text {th }}$ ed.). São Paulo, SP: Hucitec-Abrasco.

Moscovici, S. (2012). A Psicanálise, sua imagem e seu público (S. Fuhrmann, Trans.). Petrópolis, RJ: Vozes.

Ramalho, T. M. M., Maciel, S. C., Medeiros, K. T., Souza, G. L. S., Cruz, L. F. P., \& Nascimento, R. P. F. (2014). Representações sociais sobre a loucura: Intervenções inclusivas com estudantes de ensino médio. In S. C. Maciel, W. C. G. Di Lourenzo Lima, \& S. F. O. Andrade (Eds.), Saúde Mental e Dependência Química. João Pessoa, PB: Universidade Federal da Paraíba.

Romeiro, F. B., Both, L. M., Machado, A. C. A., Lawrenz, P., \& Castro, E. K. (2012). O apoio social das mulheres com câncer de mama: Revisão de artigos científicos brasileiros. Revista Psicologia e Saúde, 4(1), 27-38. Retrieved from http:// www.gpec.ucdb.br/pssa/index.php/pssa/article/viewFile/122/209

Salles, J. B., Cecilio, S. G., Pereira, N. P. A., \& Maia, L. L. Q G. N. (2012). O convívio com a mulher mastectomizada sob a óptica do companheiro. Revista de Enfermagem do Centro Oeste Mineiro, 2(1), 10-18. doi:http://dx.doi.org/10.19175/ recom.v0i0.163

Santos, D. B., \& Vieira. E. M. (2011). Imagem corporal de mulheres com câncer de mama: Uma revisão sistemática da literatura, Ciência \& Saúde Coletiva, 16(5), 2511-2522. Retrieved from http://www.producao.usp.br/bitstream/ handle/BDPI/7756/art SANTOS Imagem corporal_de_mulheres_com_cancer_de_2011. pdf? sequence $=1$

Santos, D. B. (2012). Sexualidade e imagem corporal de mulheres com câncer de mama (Doctoral dissertation, Universidade de São Paulo, Ribeirão Preto, SP, Brazil).

Santos, L. N., Dias, C. A. D. C. A., Lacerda, G. L., Barreto, W. W. P., \& Rodrigues dos Santos, T. 
(2008). Sexualidade e câncer de mama: Relatos de oito mulheres afetadas. Psicologia Hospitalar, 6(2), 2-19. Retrieved from http://pepsic. bvsalud.org/pdf/ph/v6n2/v6n2a02.pdf

Sá-Serafim, R. C. N. (2013). Corpo mastectomizado e representações sociais: Rede de significações que conduzem a ação (Doctoral dissertation, Universidade Federal da Paraíba, João Pessoa, PB, Brazil).

Scorsolini-Comin, F., dos Santos, M. A., \& Souza, L. V. (2009). Vivências e discursos de mulheres mastectomizadas: Negociações e desafios do câncer de mama. Estudos de Psicologia (Natal), 14(1), 41-50. doi:http://dx.doi.org/10.1590/ S1413-294X2009000100006

Seara, L. S., Vieira, R. X., \& Pechorro, P. S. (2012). Função sexual e imagem corporal da mulher mastectomizada. Revista Internacional de Andrología, 10(1), 104-110.

Sheppard, L. A., \& Ely, S. (2008). Breast Cancer and Sexuality. The Breast Journal, 14(2), 176181. Retrieved from http://onlinelibrary.wiley. com/doi/10.1111/j.1524-4741.2007.00550.x/ abstract

Silva, S. E. D., Vasconcelos, E. V., Santana, M. E., Araújo, J. F., Valente, J., Oliveira, J. B., Cunha, N. M. F., \& Conceição, V. M. (2012). Câncer de mama uma doença temida: Representações sociais de mulheres mastectomizadas. Revista Eletrônica Gestão \& Saúde, 3(2), 731-742. Retrieved from gestaoesaude.unb.br/index.php/ gestaoesaude/article/download/.../pdf_1
Siqueira, D. C. O., \& Faria, A. A. (2007). Corpo, saúde e beleza: Representações sociais nas revistas femininas. Comunicação, Mídia e Consumo (São Paulo), 4(9), 171-188. Retrieved from http://revistacmc.espm.br/index.php/revistacmc/article/view/95

Souza, M. R. R., Oliveira, J. F., Nascimento, E. R., \& Carvalho, E. S. S. (2013). Droga de corpo! Imagens e representações do corpo feminino em revistas brasileiras. Revista Gaúcha de Enfermagem, 34(2). doi:http://dx.doi.org/10.1590/ S1983-14472013000200008

Speer, J. J., Hillenberg, B., Sugrue, D. P., Kresge, C. L., Decker, V. B., Zakalik, D., \& Decker, D. A. (2005). Study of sexual functioning determinants in breast cancer survivors. The Breast Journal, 11(6), 440-447. Retrieved from http:// onlinelibrary.wiley.com/doi/10.1111/j.1075122X.2005.00131.x/abstract

Vala, J. (2003). A análise de conteúdo. In A. S. Silva \& J. M. Pinto (Eds.), Metodologia das ciências sociais (12 ${ }^{\text {nd }}$ ed., pp. 101-128). Lisboa: Apontamentos.

(C) The Author(s), 2018. Open Access. This article is distributed under the terms of the Creative Commons Attribution 4.0 International License (http://creativecommons.org/licenses/by/4.0/), which permits unrestricted use, distribution, and reproduction in any medium, provided you give appropriate credit to the original author(s) and the source, provide a link to the Creative Commons license, and indicate if changes were made. 